\title{
Lithuania in the Euro Area: Monetary Transmission and Macroprudential Policies*
}

\author{
Margarita Rubio \\ University of Nottingham ${ }^{\dagger}$
}

\author{
Mariarosaria Comunale \\ Bank of Lithuania ${ }^{\ddagger}$
}

October 2016

\begin{abstract}
In this paper, we develop a two-country monetary union new Keynesian general equilibrium model with housing and collateral constraints, to be calibrated for Lithuania and the rest of the euro area. Within this setting, and following the recent entrance of Lithuania in the EMU, the aim of this paper is twofold. First, we study how shocks are transmitted differently in the two regions, considering the recent common monetary policy. Then, we analyze how macroprudential policies should be conducted in Lithuania, in the context of the EMU. As a macroprudential tool, we propose a decentralized Taylortype rule for the LTV which responds to national deviations in output and house prices. We find that, given the housing market features in Lithuania, common shocks are transmitted more strongly in this country than in the rest of the euro area. In terms of macroprudential policies, results show that the optimal policy in Lithuania with respect to the euro area may have a different intensity and that it delivers substantial benefits in terms of financial stability.
\end{abstract}

Keywords: Macroprudential policy, housing market, LTV, monetary union, financial stability JEL Codes: E32, E44, F36

\footnotetext{
${ }^{*}$ The authors would like to aknowledge the help of Aurelijus Dabušinskas, Marius Jurgilas, Darius Kulikauskas, Nijole Valinskytè, Julius Stakènas, Mihnea Constantinescu, Karsten Staehr, Michael Funke, Aaro Hazak, Tomas Reichenbachas and Tomas Ramanauskas in providing the data and for very useful discussions. Special thanks to the attendants of the 8th International Conference "Economic Challenges in Enlarged Europe" and to an anonymous referee, whose comments we have incorporated. We would also like to thank the seminar participants at the Bank of Lithuania for their comments. Part of this project has been undertaken while Margarita Rubio was a visiting researcher at the Central Bank of Lithuania. She would like to thank them for their support and hospitality. All errors are ours. The conclusions expressed are those of the authors and do not necessarily represent the official views of the Bank of Lithuania.

${ }^{\dagger}$ University Park, NG7 2RD Nottingham, UK. E-mail: margarita.rubio@nottingham.ac.uk.

${ }^{\ddagger}$ Totoriu g. 4, LT-01121, Vilnius, Lithuania. E-mail: mcomunale@lb.lt
} 
"As a result of the recent global financial and economic crisis, the right consensus seems to be emerging that business cycles, which have been predominantly caused by credit growth accelerations, should be addressed with both, monetary and macroprudential policies. The MacroPru arm should be much stronger than the monetary policy arm due to a) its superior distributional effects and b) effectiveness". Raimondas Kuodis, Deputy Chairman of the Board, The Bank of Lithuania, remarks at the Conference on European Economic Integration (CEEI), November 2014

\section{Introduction}

Lithuania lost its ability to set interest rates and conduct monetary policy since the decision to follow a fixed exchange rate regimes to the euro. Now being part of the euro area itself, the country is fully integrated in the system. This has crucial implications for the Lithuanian economy given that interestrate decisions are made in favor of the euro area as a whole, with Lithuania only a tiny part in the decision making. Furthermore, some of the specific characteristics of the housing market in Lithuania can result in the single monetary policy being transmitted in this economy in a way that is different than in other countries.

There are some particularities in the Lithuanian housing markets that make it different from its euro area partners. One of these differences is, for example, mortgage contracts. Housing loans (and loans to non-financial corporations, NFCs) in Lithuania are almost exclusively made at variable interest rates (which are set for fixed periods, e.g. of up to 1 year), which are quick to respond to changes in borrowing costs in the financial markets. ${ }^{1}$ In the beginning of 2013 , about 70 per cent of new loans to households were issued at flexible interest rates. In 2014 and 2015, the proportion increased to more than 80 per cent (in 2015 the share of flexible rate loans, for both households and NFCs, reached 90 per cent). ${ }^{2}$ In the big countries of the euro area, however, the majority of of households take mortgages at a fixed rate. $^{3}$ For France and Germany the ratio of flexible-rate loans is pretty low, around 12 per cent and 15 per cent respectively, while in Spain reaches 82 per cent. This high heterogeneity is reflected in an average percentage of flexible-rate mortgage in the euro area of 45 per cent (the correspective percentage of fixed-rate loans is therefore 55 per cent).

Another issue of concern, now that Lithuania is part of the euro area, is how to correctly implement

\footnotetext{
${ }^{1}$ See Karmaziene and Varanauskiene (2014).

${ }^{2}$ Data from the website of the Bank of Lithuania (Statistics).

${ }^{3}$ See Ehrmann and Ziegelmeyer (2014) on data from ECB. They report the share of flexible-rate mortgages among the oldest active mortgages related to the household main residence.
} 
policies to promote financial stability, in accordance with the other members. The economy of Lithuania has suffered from the same financial stability problems stemming from the crisis as other countries. And as other economies, it has been trying to recover ever since and it has in fact fully recovered in terms of economic activity. The banking sector is, in any case, far better prepared to withstand such turbulences than in the outset of the most recent economic downturn. Recently, in the Financial Stability Review (Bank of Lithuania, 2015), it has been stressed that despite the growth of domestic economy and the improvements in the financial health of the private sector, credit activity remained subdued in 2014 and in the first half of 2015. However, irrespective of the better preparedness of the banking sector to withstand shocks, the overall conditions remain challenging. It is of utmost importance that the banking sector is not only capable of absorbing the previous shocks, but is also adequately prepared to face any new systemic risks and ensure sufficient credit availability for the real sector under the least favourable conditions.

Lithuania, as a new member of the euro area, has to implement its macroprudential policies in the context of this new economic setting, by interacting with the other monetary union members, that indeed share the same monetary policy. The Bank of Lithuania pursues macroprudential policy at the national level and monitors, assesses, and does its best to limit the macroprudential risk for the stability of the domestic financial system; in doing so it has the possibility to cooperate with the ECB and other national and international institutions. One of the intermediate objectives that the Bank of Lithuania has set is to mitigate excessive credit growth and too high leverage.

In this paper, we aim first at illustrating the monetary policy transmission in Lithuania in the context of the euro area. Then, we propose the implementation of a macroprudential tool, based on the LTV that aims at maximizing welfare. ${ }^{5}$ The basic modelling setup constitutes a two-country new Keynesian DSGE model with financial frictions. In each country, there is a group of individuals that are credit constrained and need housing collateral to obtain loans. Countries trade goods, and savers in each country have access to foreign assets. Within this setting, we study how macroprudential policies should be conducted in Lithuania, in the context of the euro area. As a macroprudential tool, we propose

\footnotetext{
${ }^{4}$ In our model, the LTV ratio will be calibrated to match the average (market) LTV in steady state. However the market LTV can vary depending on economic conditions and it may be different with respect to the imposed LTV cap set by authority. When the LTV cap is high, the collateral constraint is less tight. And, since the constraint in this model is binding, borrowers will borrow as much as they are allowed to. Lowering the LTV tightens the constraint and therefore restricts the loans that borrowers can obtain.

${ }^{5}$ Here we follow Angelini et al. (2014) in which they assume that the loss function in the economy also contains financial variables. Therefore, we use it as a proxy for financial stability, which is seen as the actual aim of macroprudential policy (Galati and Moessner, 2011).
} 
a decentralized Taylor-type rule for the LTV which responds to national deviations in credit from its steady state. We also include the common monetary policy with a Taylor rule, consistent with the ECB target of price stability, with interest-rate smoothing for interest-rate setting by a single central bank.

Results show that common shocks are transmitted in a stronger way in Lithuania than in the rest of the euro area, given that the former country has variable-rate mortgages and a higher LTV cap than its European partners. With respect to macroprudential policies, we find that the optimal policy is that Lithuania may have a different intensity in its LTV setting than the rest of the euro area, given that monetary policy is more effective in this country. We also find that the LTV rule is welfare enhancing for the whole monetary union, although there exists a welfare trade-off between borrowers and savers. This is explained because, on the one hand, macroprudential policies bring a more stable financial system, on the other hand, monetary policy may be less effective and inflation volatility can increase.

The paper is organized as follows: section 2 brefly adresses our main contribution, linking it to the recent literature, section 3 describes the model, section 4 presents the parameter values, section 5 presents the dynamics of the model, section 6 analyzes optimal macroprudential policies and section 7 concludes.

\section{Literature review and our contribution}

This paper relates to this policy making issue linking it to different strands of the literature. There is an extensive literature that shows that institutional, consumption, financial or housing market heterogeneity can endanger the optimality of EMU as a currency area (See Maclennan et al., 1998; ECB, 2009; Rubio, 2014). The model constitutes a two-country version of the seminal paper of Iacoviello (2005), that introduces a financial accelerator that works through the housing sector, in the flavor of Aspachs and Rabanal (2010). However, it introduces cross-country housing-market heterogeneity as in Rubio (2014). This paper is also related to the recent literature on macroprudential and monetary policies in Iacoviello-type models such in the aforementioned Kannan, Rabanal and Scott (2012) or Rubio and Carrasco-Gallego $(2013,2014)$. However, it explores the issue in a two-country setting as in BrzozaBrzezina et al. (2015). The novelty of this paper is its special application to the case of Lithuania in a 2 countries framework with respect to the rest of the euro area. There is also some literature looking at the response of the Lithuanian economy to a common ECB rate shock. In particular, Stakenas and Stasiukynaitè (2016), through an empirical structural VAR, look at the responses of GDP, HICP (excl. 
energy) and credit to non-financial institutions and households in Lithuania (and to GDP and HICP only for the euro area) due to a $100 \mathrm{bp}$ increase in the Euribor. Their results are in line with some previous studies such as Georgiadis (2015) and Errit and Uuskula (2014) concluding that the response to a monetary policy shock coming from the euro area is quite substancial.

\section{Model Setup}

We consider an infinite-horizon, two-country economy inside a monetary union. The home country is denoted by LIT and the rest of the union by EUR. Households consume, work, and demand real estate. There is a financial intermediary in each country that provides mortgages and accepts deposits from consumers. Each country produces one differentiated intermediate good, but households consume goods from both countries. For simplicity, housing is a non-traded good. We assume that labor is immobile across the countries. ${ }^{6}$ Firms follow a standard Calvo problem (after Calvo, 1983). In this economy, both final and intermediate goods are produced. Prices are sticky in the intermediate-goods sector. Monetary policy is conducted by a single central bank that responds to a weighted average of inflation in both countries. Analogous to the setting of the interest rate, there is a rule for the setting of the LTV, which serves as a macroprudential measure. We allow for housing-market heterogeneity across the countries.

\subsection{The Consumer's Problem}

There are three types of consumers in each country: unconstrained consumers, constrained consumers who borrow at a variable rate, and constrained consumers who borrow at a fixed rate. The proportion of each type of borrower is fixed and exogenous. ${ }^{7}$ Consumers can be constrained or unconstrained in the sense that constrained individuals need to collateralize their debt repayments in order to borrow from the financial intermediary. Interest payments in the next period cannot exceed a proportion of the future value of the current house stock. In this way, the financial intermediary ensures that borrowers are going to be able to fulfill their debt obligations in the next period. As in Iacoviello (2005), We assume that

\footnotetext{
${ }^{6}$ This is a standard simplifying assumption, since the focus of the paper is on financial markets. We aknowledge the fact that labor mobility has been a factor within the euro area, however is not covered here. This is especially true for Lithuania. This resulted in labor shortage in the country and a significant emigration.

${ }^{7}$ According to the European Mortgage Federation, the type of mortgage contracts across countries responds to a large extent to institutional or cultural factors, which are out of the scope of the present model. In the short run, the proportion of each type of mortgage contract can fluctuate, but, typically, it does not imply a change in the fixed- or variable-rate category of the country.
} 
constrained consumers are more impatient than unconstrained ones. ${ }^{8}$ There is a financial intermediary in each country. The financial intermediary in each country accepts deposits from domestic savers, and it extends both fixed- and variable-rate loans to domestic borrowers.

\subsubsection{Unconstrained Consumers (Savers)}

Unconstrained consumers in LIT maximize as follows:

$$
\max E_{0} \sum_{t=0}^{\infty} \beta^{t}\left(\ln C_{t}^{u}+j \ln H_{t}^{u}-\frac{\left(L_{t}^{u}\right)^{\eta}}{\eta}\right)
$$

Here, $E_{0}$ is the expectation operator, $\beta \in(0,1)$ is the discount factor for savers, and $C_{t}^{u}, H_{t}^{u}$, and $L_{t}^{u}$ are consumption at $t$, the stock of housing, and hours worked, respectively. $j$ represents the weight of housing in the utility function. $1 /(\eta-1)$ is the aggregate labor-supply elasticity.

Consumption is a bundle of domestically and foreign-produced goods, defined as: $C_{t}^{u}=\left(C_{L I T t}^{u}\right)^{n}\left(C_{E U R t}^{u}\right)^{1-n}$, where $n$ is the size of LIT.

The budget constraint for LIT is as follows:

$$
\begin{gathered}
P_{L I T t} C_{L I T t}^{u}+P_{E U R t} C_{E U R t}^{u}+Q_{L I T t} H_{t}^{u}+R_{L I T t-1} B_{t-1}^{u}+R_{t-1} D_{t-1}+\frac{\psi}{2} D_{t}^{2} \leq Q_{t} H_{t-1}^{u}+ \\
W_{t}^{u} L_{t}^{u}+B_{t}^{u}+D_{t}+P_{L I T t} F_{t}+P_{L I T t} S_{t}
\end{gathered}
$$

where $P_{L I T t}$ and $P_{E U R t}$ are the prices of the goods produced in Countries LIT and EUR, respectively, $Q_{t}$ is the housing price in LIT, $H_{t}^{u}$ is the stock of housing and $W_{t}^{u}$ is the wage for unconstrained consumers. $B_{t}^{u}$ represents domestic bonds denominated in the common currency. $R_{L I T t}$ is the nominal interest rate in LIT. Positive bond holdings signify borrowing, and negative signify savings. However, as we will see, this group will choose not to borrow at all: they are the savers in this economy. $D_{t}$ are foreignbond holdings by savers in LIT, who have indeed access to the international financial market. $R_{t}$ is the nominal rate of foreign bonds, which are denominated in euros. As is common in the literature, to ensure stationarity of net foreign assets we introduced a small quadratic cost of deviating from zero foreign borrowing, $\frac{\psi}{2} D_{t}^{2}$. Savers obtain interest on their savings. $S_{t}$ and $F_{t}$ are lump-sum profits received from the firms and the financial intermediary in LIT, respectively.

\footnotetext{
${ }^{8}$ This assumption ensures that the borrowing constraint is binding in the steady state and that the economy is endogenously split into borrowers and savers.
} 
Dividing by $P_{L I T t}$, we can rewrite the budget constraint in terms of goods $\mathrm{LIT}^{9}$ :

$C_{L I T t}^{u}+\frac{P_{E U R t}}{P_{L I T t}} C_{E U R t}^{u}+q_{L I T t} H_{t}^{u}+\frac{R_{L I T t-1} b_{t-1}^{u}}{\pi_{L I T t}}+\frac{R_{t-1} d_{t-1}}{\pi_{L I T t}}+\frac{\psi}{2} d_{t}^{2} \leq q_{L I T t} H_{t-1}^{u}+w_{t}^{u} L_{t}^{u}+b_{t}^{u}+d_{t}+F_{t}+S_{t}$,

where $\pi_{L I T t}$ denotes inflation for the goods produced in LIT, defined as $P_{\text {LITt }} / P_{\text {LITt-1 }}$.

Maximizing (1) subject to (3), we obtain the first-order conditions for the unconstrained group:

$$
\begin{gathered}
\frac{C_{L I T t}^{u}}{C_{E U R t}^{u}}=\frac{n P_{E U R t}}{(1-n) P_{L I T t}} \\
\frac{1}{C_{L I T t}^{u}}=\beta E_{t}\left(\frac{R_{L I T t}}{\pi_{L I T t+1} C_{L I T t+1}^{u}}\right), \\
\frac{1-\psi d_{t}}{C_{L I T t}^{u}}=\beta E_{t}\left(\frac{R_{t}}{\pi_{L I T t+1} C_{L I T t+1}^{u}}\right), \\
w_{t}^{u}=\left(L_{t}^{u}\right)^{\eta-1} \frac{C_{L I T t}^{u}}{n} \\
\frac{j}{H_{t}^{u}}=\frac{n}{C_{L I T t}^{u}} q_{L I T t}-\beta E_{t} \frac{n}{C_{L I T t+1}^{u}} q_{L I T t+1} .
\end{gathered}
$$

Equation (4) equates the marginal rate of substitution between goods to the relative price. Equation (5) is the Euler equation for consumption. Equation (6) is the first-order condition for net foreign assets. Equation (7) is the labor-supply condition. These equations are standard. Equation (8) is the Euler equation for housing and states that at the margin the benefits from consuming housing have to be equal to the costs.

Combining (5) and (6) we obtain a non-arbitrage condition between home and foreign bonds: ${ }^{10}$

$$
R_{L I T t}=\frac{R_{t}}{\left(1-\psi d_{t}\right)}
$$

Since all consumption goods are traded and there are no barriers to trade, we assume in this paper

\footnotetext{
${ }^{9}$ The variables in small letters are taken divided by $P_{L I T t}$.

${ }^{10}$ The log-linearized version of this equation could be interpreted as the uncovered interest-rate parity.
} 
that the law of one price holds:

$$
P_{\text {LITt }}=P_{\text {LITt }}^{*}
$$

where variables with a star denote foreign variables and $P_{L I T t}^{*}$ is the foreign price of goods produced at home.

\subsubsection{Constrained Consumers (Borrowers)}

Constrained consumers in LIT are of two types: those who borrow at a variable rate and those who do so at a fixed rate. The difference between them is the interest rate they are charged. The variablerate constrained consumer faces $R_{L I T t}$, which will coincide with the rate set by the central bank. The fixed-rate borrower pays $\bar{R}_{L I T t}$, derived from the financial intermediary's problem. The proportion of variable-rate consumers in LIT is constant and exogenous and is equal to $\alpha_{L I T} \in[0,1]$.

Constrained consumers are more impatient than unconstrained ones, that is $\widetilde{\beta}<\beta$ in terms of discount factors for borrowers and savers respectively. Constrained consumers face a collateral constraint: the expected debt repayment in the next period cannot exceed a proportion of the expectation of tomorrow's value of today's stock of housing:

$$
\begin{aligned}
& E_{t} \frac{R_{L I T t}}{\pi_{L I T t+1}} b_{t}^{c v} \leq k_{L I T t} E_{t} q_{L I T t+1} H_{t}^{c v}, \\
& E_{t} \frac{\bar{R}_{L I T t}}{\pi_{L I T t+1}} b_{t}^{c f} \leq k_{L I T t} E_{t} q_{L I T t+1} H_{t}^{c f},
\end{aligned}
$$

where equations (11) and (12) represent the collateral constraint for the variable- and fixed-rate borrower, respectively. $k_{L I T t}$ can be interpreted as the loan-to-value ratio in LIT. Notice that such models with collateral constraints, the LTV is typically considered exogenous. At the macroeconomic level, LTVs partly depend on exogenous factors such as regulation. This parameter is usually calibrated to match the average (market) LTV in the country analyzed. ${ }^{11}$ However, in this model, it can vary depending on economic conditions, as a macroprudential policy variable. ${ }^{12}$ For the setting of the fixed interest

\footnotetext{
${ }^{11}$ Due to data availability, we use the average new loans' LTV at origination.

${ }^{12}$ It has to be taking into account that in reality, macroprudential LTV caps are not always binding. Even a stable LTV cap inherently has a countercyclical effect as it is less binding after a crisis but is likely to become more binding as credit and housing prices pick up during the financial cycle (Matkenaite et al., 2016).
} 
rate, $\bar{R}_{L I T t}$, we follow Rubio (2011). We assume that there a financial intermediary in each country that accepts deposits from savers and extends both fixed and variable-rate mortgages to borrowers. For the two types of mortgage to be offered, the fixed-interest rate has to be such that the intermediary is indifferent between lending at a variable or fixed rate. $\bar{R}_{L I T t}$ will be an aggregate interest rate that contains information on all the past fixed-interest rates associated with past debt. Each period, this aggregate interest rate is updated with a new fixed interest rate that is an average discount average of all future variable interest rates.

Without loss of generality, we present the problem for the variable-rate borrower since for the fixed rate it is symmetrical. Variable-rate borrowers maximize their lifetime utility function:

$$
\max E_{0} \sum_{t=0}^{\infty} \widetilde{\beta}^{t}\left(\ln C_{t}^{c v}+j \ln H_{t}^{c v}-\frac{\left(L_{t}^{c v}\right)^{\eta}}{\eta}\right),
$$

where $C_{t}^{c v}=\left(C_{L I T t}^{c v}\right)^{n}\left(C_{E U R t}^{c v}\right)^{1-n}$, subject to the budget constraint (in terms of good LIT):

$$
C_{L I T t}^{c v}+\frac{P_{E U R t}}{P_{L I T t}} C_{E U R t}^{c v}+q_{L I T t} H_{t}^{c v}+\frac{R_{L I T t-1} b_{t-1}^{c v}}{\pi_{L I T t}} \leq q_{L I T t} H_{t-1}^{c v}+w_{t}^{c v} L_{t}^{c v}+b_{t}^{c v},
$$

and subject to the collateral constraint (11). Notice that variable-rate borrowers repay all debt every period and acquire new debt at the current new interest rate. This assumption implies that the interest rate on variable-rate mortgages is revised every period for the whole stock of debt and changed according to the policy rate. ${ }^{13}$ To make the problem for fixed-rate borrowers symmetrical and analogous to existing models with borrowing constraints, we assume the same debt-repayment structure for this type of borrower. Obviously, fixed-rate contracts are not revised every period. However, to make the model more realistic, but still tractable, the fixed-interest rate will be such that a revised fixed rate will be applied only on new debt, keeping constant the interest rate applied to existing debt. In this way, we reconcile the structure of the model with the fact that fixed-rate contracts are long term.

The first-order conditions for these consumers are as follows:

$$
\frac{C_{L I T t}^{c v}}{C_{E U R t}^{c v}}=\frac{n P_{E U R t}}{(1-n) P_{L I T t}}
$$

\footnotetext{
${ }^{13}$ This assumption is consistent with reality, in which variable-interest rates are revised very frequently and changed according to an interest-rate index tied to the interest rate set by the central bank.
} 


$$
\begin{gathered}
\frac{n}{C_{L I T t}^{c v}}=\widetilde{\beta} E_{t}\left(\frac{n R_{L I T t}}{\pi_{L I T t+1} C_{L I T t+1}^{c v}}\right)+\lambda_{t}^{c v} R_{L I T t}, \\
w_{t}^{c v}=\left(L_{t}^{c v}\right)^{\eta-1} \frac{C_{L I T t}^{c v}}{n}, \\
\frac{j}{H_{t}^{c v}}=\frac{n}{C_{L I T t}^{c v}} q_{L I T t}-\widetilde{\beta} E_{t} \frac{n}{C_{L I T t+1}^{c v}} q_{L I T t+1}-\lambda_{t}^{c v} k_{L I T t} E_{t} q_{L I T t+1} \pi_{L I T t+1} .
\end{gathered}
$$

These first-order conditions differ from those of unconstrained individuals. In the case of constrained consumers, the Lagrange multiplier on the borrowing constraint $\left(\lambda_{t}^{c v}\right)$ appears in equations (16) and (18). As in Iacoviello (2005), the borrowing constraint is always binding, so that constrained individuals borrow the maximum amount they are allowed, and their saving is zero. The problem for consumers is analogous in country EUR.

\subsection{Firms}

\subsubsection{Final-Goods Producers}

In LIT, there is a continuum of final-goods producers that aggregate intermediate goods according to the production function:

$$
Y_{L I T t}^{k}=\left[\int_{0}^{1} Y_{L I T t}^{k}(z)^{\frac{\varepsilon-1}{\varepsilon}} d z\right]^{\frac{\varepsilon}{\varepsilon-1}},
$$

where $\varepsilon>1$ is the elasticity of substitution among intermediate goods.

The total demand of intermediate-good $z$ is given by $Y_{L I T t}(z)=\left(\frac{P_{L I T t}(z)}{P_{L I T t}}\right)^{-\varepsilon} Y_{L I T t}$, and the price index is $P_{\text {LITt }}=\left[\int_{0}^{1} P_{\text {LITt }}(z)^{1-\varepsilon} d z\right]^{\frac{1}{\varepsilon-1}}$.

\subsubsection{Intermediate-Goods Producers}

The intermediate-goods market is monopolistically competitive. Following Iacoviello (2005), intermediate goods are produced according to the following production function:

$$
Y_{L I T t}(z)=\xi_{t}\left(L_{t}^{u}(z)\right)^{\gamma_{L I T}}\left(L_{t}^{c}(z)\right)^{\left(1-\gamma_{L I T}\right)}
$$


where $\xi_{t}$ represents technology. We assume that $\log \xi_{t}=\rho_{\xi} \log \xi_{t-1}+u_{\xi t}$, where $\rho_{\xi}$ is the autoregressive coefficient and $u_{\xi t}$ is a normally distributed shock to technology. $\gamma_{L I T} \in[0,1]$ measures the relative size of each group in terms of labor ${ }^{14} . L_{t}^{c}$ is labor supplied by constrained consumers, defined as $\alpha_{L I T} L_{t}^{c v}+$ $\left(1-\alpha_{L I T}\right) L_{t}^{c f}$

The first-order conditions for labor demand are the following: ${ }^{15}$

$$
\begin{gathered}
w_{t}^{u}=\frac{1}{X_{t}} \gamma_{L I T} \frac{Y_{L I T t}}{L_{t}^{u}}, \\
w_{t}^{c v}=w_{t}^{c f}=\frac{1}{X_{t}}\left(1-\gamma_{L I T}\right) \frac{Y_{L I T t}}{L_{t}^{c}},
\end{gathered}
$$

where $X_{t}$ is the markup, or the inverse of marginal cost.

The price-setting problem for the intermediate-goods producers is a standard Calvo-Yun case. An intermediate-goods producer sells goods at price $P_{L I T t}(z)$, and $1-\theta$ is the probability of being able to change the sale price in every period. The optimal reset price $P_{L I T t}^{O P T}(z)$ solves the following:

$$
\sum_{k=0}^{\infty}(\theta \beta)^{k} E_{t}\left\{\Lambda_{t, k}\left[\frac{P_{L I T t}^{O P T}(z)}{P_{L I T t+k}}-\frac{\varepsilon /(\varepsilon-1)}{X_{t+k}}\right] Y_{L I T t+k}^{O P T}(z)\right\}=0
$$

The aggregate price level is given as follows:

$$
P_{L I T t}=\left[\theta P_{L I T t-1}^{1-\varepsilon}+(1-\theta)\left(P_{L I T t}^{O P T}\right)^{1-\varepsilon}\right]^{1 /(1-\varepsilon)}
$$

Using (23) and (24) and log-linearizing, we can obtain the standard forward-looking Phillips curve ${ }^{16}$.

The firm problem is similar in EUR.

\subsection{Aggregate Variables and Market Clearing}

Given $\alpha_{L I T}$, the fraction of variable-rate borrowers in LIT, we can define aggregates across constrained consumers as the sum of variable-rate and fixed-rate aggregates, so that $C_{t}^{c} \equiv \alpha_{L I T} C_{t}^{c v}+\left(1-\alpha_{L I T}\right) C_{t}^{c f}$, $H_{t}^{c} \equiv \alpha_{L I T} H_{t}^{c v}+\left(1-\alpha_{L I T}\right) H_{t}^{c f}$ and $b_{t}^{c} \equiv \alpha_{L I T} b_{t}^{c v}+\left(1-\alpha_{L I T}\right) b_{t}^{c f}$.

Therefore, economy-wide aggregates in LIT are $C_{t} \equiv C_{t}^{u}+C_{t}^{c}, L_{t} \equiv L_{t}^{u}+L_{t}^{c}$. The aggregate supply

\footnotetext{
${ }^{14}$ It can be seen as labor-income share and proxy for the differences in debt to GDP.

${ }^{15}$ Symmetry across firms allows avoiding index $z$.

${ }^{16}$ The Phillips curve is as the following: $\hat{\pi}_{L I T t}=\beta \hat{\pi}_{L I T t+1}-\widetilde{k} \hat{x}_{t}+u_{L I T t}$, where $\hat{x}$ is $1 /$ real marginal cost and $\widetilde{k}=$ $[(1-\theta)(1-\beta \theta) / \theta]$.
} 
of housing is fixed, so that market clearing requires $H_{t} \equiv H_{t}^{u}+H_{t}^{c}=H .{ }^{17}$

The market clearing condition for the final good in LIT is $n Y_{\text {LITt }}=n C_{L I T t}+(1-n) C_{L I T t}^{*}+$ $n \frac{\psi}{2} d_{t}^{2}$. Domestic financial markets clear: $b_{t}^{c}=b_{t}^{u}$. The world bond market clearing condition is $n d_{t}+$ $(1-n) \frac{P_{E U R t}}{P_{\text {LITt }}} d_{t}^{*}=0$, where $d_{t}$ denotes the foreign bonds in real terms. The net foreign asset position follows $d_{t}=\frac{R_{t-1}}{\left(1-\psi d_{t}\right) \pi_{L I T t}} d_{t-1}+Y_{L I T t}-C_{L I T t}-\frac{P_{E U R t}}{P_{L I T t}} C_{E U R t}$. Everything is similar in EUR.

\subsection{Monetary Policy}

The model closes with a Taylor rule, with interest-rate smoothing for interest-rate setting by a single central bank, ${ }^{18}$

$$
R_{t}=\left(R_{t-1}\right)^{\rho}\left(\left[\left(\pi_{L I T t}\right)^{n}\left(\pi_{E U R t}\right)^{(1-n)}\right]^{\left(1+\phi_{\pi}\right)} R\right)^{1-\rho} \varepsilon_{R, t}
$$

$0 \leq \rho \leq 1$ is the parameter associated with interest-rate inertia. $\left(1+\phi_{\pi}\right)$ measures the sensitivity of interest rates to current inflation. $\varepsilon_{R, t}$ is a white noise shock process with zero mean and variance $\sigma_{\varepsilon}^{2} . R$ is the interest rate in steady state. This rule is consistent with the primary objective of the ECB being price stability.

\subsection{Macroprudential Policy}

As an approximation for a macroprudential policy, we consider a Taylor-type rule for the loan-to-value ratio. In standard models, the LTV ratio is a fixed parameter which is not affected by economic conditions. However, we can think of regulations of LTV ratios as a way to moderate credit booms. When the LTV (cap) ratio is high, the collateral constraint is less tight. And, since the constraint here is binding, borrowers will borrow as much as they are allowed to. Lowering the LTV tightens the constraint and therefore restricts the loans that borrowers can obtain. Recent research on macroprudential policies has proposed Taylor-type rules for the LTV ratio so that it reacts inversely to variables such that the growth rates of GDP, credit, the credit-to-GDP ratio or house prices. ${ }^{19}$ We decided to make the rule more

\footnotetext{
${ }^{17}$ An endogenous supply of housing could be easily introduced in a two-sector version of this model. However, the qualitative results would not change for the demand side of the model which is the focus of this paper. For two-sector models, see, for example, Iacoviello and Smets (2006) or Iacoviello and Neri (2010).

${ }^{18}$ This type of rule is also used in other monetary-union models. See Iacoviello and Smets (2006) or Aspachs and Rabanal (2008). Furthermore, as shown in Iacoviello (2005) and Rubio and Carrasco-Gallego (2013), a rule that only responds to inflation enhances the financial accelerator.

${ }^{19}$ With a macroprudential orientation, Kannan et al., (2012) also examine a monetary policy rule that reacts to prices, output and changes in collateral values with a macroprudential instrument based on the LTV; Funke and Paetz (2012) consider a non-linear version of a macroprudential rule for the LTV.
} 
parsimonious allowing the LTV ratio to eract to borrowing. This will help for a further study on the interactions with monetary policy. These rules can be a simple illustration of how a macroprudential policy could work in practice. Here, we assume that there exists a macroprudential Taylor-type rule for the LTV ratio, so that it responds to deviations of credit from its steady state. ${ }^{20}$ We consider a decentralized macroprudential policy in which each country can implement its own rule:

$$
\begin{gathered}
k_{L I T t}=k_{S S L I T}\left(\frac{b_{L I T t}}{b_{L I T}}\right)^{-\phi_{L I T}^{k}}, \\
k_{E U R t}=k_{S S E U R}\left(\frac{b_{E U R t}}{b_{E U R}}\right)^{-\phi_{E U R}^{k}} .
\end{gathered}
$$

where $k_{S S L I T}, b_{L I T}$ are the steady-state values for the loan-to-value ratio and borrowing in LIT. $\phi_{L I T}^{k} \geq 0$ measures the response of the loan-to-value to deviations of borrowing from its steady state. This kind of rule would be countercyclical, delivering a lower LTV ratio in credit booms, therefore restricting the credit in the economy.

\subsection{Welfare Measure}

In order to provide a measure for welfare, we numerically evaluate how cross-country asymmetries affect welfare for a given policy rule and for technology shocks. As discussed in Benigno and Woodford (2012), the two approaches that have recently been used for welfare analysis in DSGE models include either characterizing the optimal Ramsey policy, or solving the model using a second-order approximation to the structural equations for given policy and then evaluating welfare using this solution. As in Mendicino and Pescatori (2007), we take this latter approach to be able to evaluate the welfare of the three types of agents separately. ${ }^{21}$ The individual welfare for savers and borrowers in LIT is defined, respectively, as follows:

\footnotetext{
${ }^{20}$ We have also experimented with rules that react to output and house prices and results for the dynamics of the model are similar. The first variable would correspond to the objective of the macroprudential regulator to moderate booms in the economy that could lead to an excessive credit growth. Drehmann et al. (2010) also point out that the deviations of credit from its long-term trend are very good indicators of the increase in systemic risk, which is the macroprudential attention. As for the house prices, given collateral constraints, they are the key causal variable for the dynamics of loans to households, and it appears to correspond to the actual behavior of policymakers (Angelini et al., 2012).

${ }^{21}$ We used the software Dynare to obtain a solution for the equilibrium implied by a given policy by solving a second-order approximation to the constraints, then evaluating welfare under the policy using this approximate solution, as in SchmittGrohe and Uribe (2004). See Monacelli (2006) for an example of the Ramsey approach in a model with heterogeneous consumers.
} 


$$
\begin{aligned}
V_{u, t} & \equiv E_{t} \sum_{m=0}^{\infty} \beta^{m}\left(\ln C_{t+m}^{u}+j \ln H_{t+m}^{u}-\frac{\left(L_{t+m}^{u}\right)^{\eta}}{\eta}\right) \\
V_{c v, t} & \equiv E_{t} \sum_{m=0}^{\infty} \widetilde{\beta}^{m}\left(\ln C_{t+m}^{c v}+j \ln H_{t+m}^{c v}-\frac{\left(L_{t+m}^{c v}\right)^{\eta}}{\eta}\right),
\end{aligned}
$$

Following Mendicino and Pescatori (2007), we define social welfare in LIT as a weighted sum of the individual welfare for the different types of households:

$$
V_{t}=(1-\beta) V_{u, t}+(1-\widetilde{\beta})\left[\alpha_{A} V_{c v, t}+\left(1-\alpha_{A}\right) V_{c f, t}\right]
$$

Borrowers and savers' welfare are weighted by $(1-\widetilde{\beta})$ and $(1-\beta)$, respectively, so that the two groups receive the same level of utility from a constant consumption stream. Everything is symmetrical for EUR.

Total welfare is defined as a weighted sum of the welfare in the two countries:

$$
W_{t}=n V_{t}+(1-n) V_{t}^{*}
$$

In order to make the results more intuitive, we present welfare changes in terms of consumption equivalents. We use as a benchmark the welfare evaluated when the macroprudential policy is not active and compare it with the welfare obtained when such policy is implemented. ${ }^{22}$

\section{Parameter Values}

Parameters are calibrated to reflect the economy of Lithuania and the rest of the euro area. Some of the parameters are standard and are common for both economies and some others will be specifically calibrated for each country. Tables 1 and 2 present a summary of the parameter values.

Discount factors are set to be common in both economies, following the standard values in the literature. The discount factor for savers, $\beta$, is set to $0.99 .{ }^{23}$ The discount factor for borrowers, $\widetilde{\beta}$, is set to $0.98 .^{24}$ The steady-state weight of housing in the utility function, $j$, is set to 0.12 and 0.14 , in the euro area and Lithuania, respectively. This parameter pins down the ratio of housing wealth to GDP,

\footnotetext{
${ }^{22}$ We follow Ascari and Ropele (2009).

${ }^{23}$ Since the seminal paper by Kydland and Prescott (1982), the literature on DSGE models considers a calibrated value of the discount factor of 0.99 as the standard value for this parameter.

${ }^{24}$ Lawrance (1991) estimated discount factors for poor consumers at between 0.95 and 0.98 at quarterly frequency.
} 
since the latter in the steady state is a function of this parameter. ${ }^{25}$ We set $\eta=2$, implying a value of the labor supply elasticity of $1 .{ }^{26}$ For the loan-to-value ratio we consider a steady-state value of 0.68 and 0.78 , for the euro area and Lithuania, respectively, taking the LTV ratio observed in the data. ${ }^{27}$ The labor-income share of unconstrained consumers, $\gamma$, is set to $0.7{ }^{28}$ We pick a value of 6 for $\varepsilon$, the elasticity of substitution among intermediate goods. This value implies a steady-state markup of 1.2. The probability of not changing prices, $\theta$, is set to 0.75 , implying that prices change every four quarters on average. For the Taylor rule parameters, we used $\rho=0.8, \phi_{\pi}=0.5$. The first value reflects a realistic degree of interest-rate smoothing. ${ }^{29} \phi_{\pi}$ is consistent with the original parameters proposed by Taylor in 1993. We consider $\alpha$, the proportion of variable-rate mortgages, to be 0.45 and 0.82 , in the euro area and Lithuania, respectively. The size of Lithuania is considered to be $0.35 \% .{ }^{30}$ A technology shock was a 1 per cent positive technology with 0.9 persistence. ${ }^{31}$ Tables 1 and 2 present a summary of the parameter values.

\begin{tabular}{|c|c|c|c|}
\hline \multicolumn{4}{|c|}{ Table 1: Country-specific parameter values } \\
\hline & EUR & LIT & \\
\hline$j$ & 0.12 & 0.14 & Weight of housing in utility function \\
\hline$k$ & 0.68 & 0.78 & Average loan-to-value ratio \\
\hline$\alpha$ & 0.45 & 0.82 & Degree of variability of interest rate \\
\hline$n$ & 0.9965 & 0.0035 & Country size \\
\hline
\end{tabular}

\footnotetext{
${ }^{25}$ Following Iacoviello and Neri (2010), we use 1.2, value that reflects the ratio of housing wealth to GDP across most industrialized countries as a proxy for the euro area. This ratio is higher though in Lithuania.

${ }^{26}$ Microeconomic estimates usually suggest values in the range of 0 and 0.5 (for males). Domeij and Flodén (2006) showed that in the presence of borrowing constraints this estimate could have a downward bias of 50 per cent.

${ }^{27}$ Note that the macroprudential LTV cap in Lithuania since 2011 is 85 per cent, which is higher than the average LTV in the last decade.

${ }^{28}$ This value is in the range of the estimates of Iacoviello (2005) and Iacoviello and Neri (2010) for the US, and Campbell and Mankiw (1991) for the US, Canada, France, and Sweden. Therefore, we take it as valid for most of the countries of the euro area.

${ }^{29}$ See McCallum (2001).

${ }^{30}$ Even though Lithuania is such a small country, we still want to keep a two-country setting to be able to study the interaction between policies in Lithuania and the rest of the euro area and potentially centralized vs. decentralized policies.

${ }^{31}$ This high persistence value for technology shocks is consistent with what is commonly reported in the literature. Smets and Wouters (2002) estimated a value of 0.822 for this parameter in Europe; Iacoviello and Neri (2010) estimated it as 0.93 for the US.
} 
Table 2: Common parameter Values

\begin{tabular}{|c|c|c|}
\hline \hline$\beta$ & .99 & Discount factor for savers \\
\hline$\widetilde{\beta}$ & .98 & Discount factor for borrowers \\
\hline$\eta$ & 2 & Parameter associated with labor elasticity \\
\hline$\gamma$ & .70 & Labor-Income share for savers \\
\hline$\varepsilon$ & 6 & Elasticity of substitution among intermediate goods \\
\hline$\rho$ & 0.8 & Interest-rate smoothing in Taylor rule \\
\hline$\phi_{\pi}$ & .5 & Inflation parameter in Taylor rule \\
\hline$\rho_{\xi}$ & 0.9 & Technology shock persistence \\
\hline
\end{tabular}

\section{Shock Transmission}

In this section, we study first the dynamics of the model by showing impulse-responses to a monetary policy shock, a technology shock and a house price shock, abstracting from macroprudential policies, and using the parameter values shown in the previous section. Given the structural differences between Lithuania and the rest of the euro zone, the same monetary policy shock, coming from the ECB, is potentially going to be transmitted in a different way in Lithuania. Other shocks, i.e. technology and housing demand, even if they are common, will have a different impact on the two economies and will have to be accommodated by the single monetary policy.

\subsection{Impulse responses to a monetary policy shock}

Figure 1 presents impulse responses to a monetary policy shock. This represents a decrease in the interest rate by the ECB. The common monetary policy shock is transmitted to both economies in a different way. Although the effects on house prices and inflation are very similar for Lithuania and the rest of the euro area, the effects on borrowing differ. In particular, we see that in Lithuania the increase in borrowing is stronger than in the rest of the euro area. Lithuania is an economy in which rates are variable, as opposed to the big countries of the EMU. Therefore, the same drop in the policy rate is transmitted in a direct way to the borrowing rate, causing credit to increase sharply. On the other hand, the LTV in Lithuania is also larger than in the rest of the euro area. This creates a higher financial accelerator and thus, the same change in the interest rate and house prices affect the collateral constraint by more, making borrowing more sensitive to monetary policy changes. This stronger increase in credit 

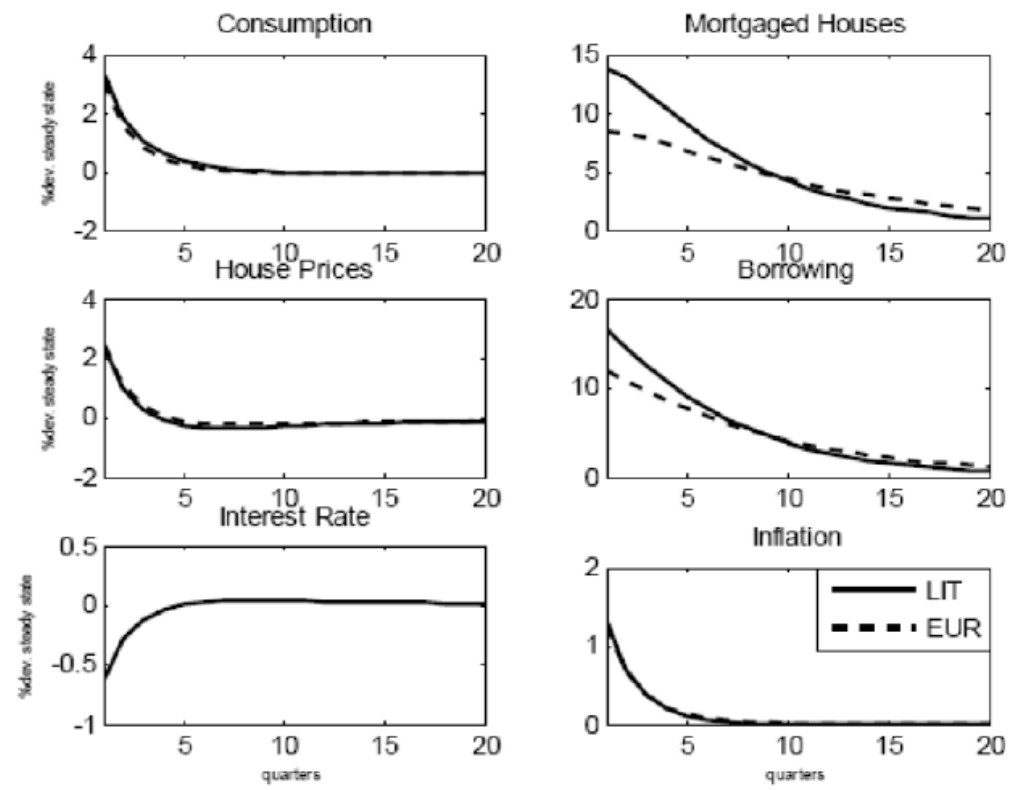

Figure 1: Impulse Responses to a Monetary Policy shock

creates an extra increase in consumption demand in Lithuania.

\subsection{Impulse Responses to a Technology Shock}

When there is a common technology shock, demand increases in a similar way in both countries (Figure 2). In the same way, inflation decreases both in LIT and EUR and reduces the interest rate. The main difference comes in the financial side. Given that Lithuania has a higher LTV than the rest of the Euro area and the interest rate is variable, borrowing increases by more in Lithuania following the fall in the common policy rate. As in the previous case, the increase of mortgaged houses is higher in Lithuania. For this kind of shock, we observe a slightly larger increase in house prices in Lithuania, with respect to the rest of the euro area.

\subsection{Impulse Responses to a House Price Shock}

Figure 3 describes impulse responses to a house price shock both in Lithuania and in the rest of the euro area. We see from the figure that the house price shock is stronger in Lithuania and this causes credit to increase by more in this country. This creates strong effects on mortgaged houses and on consumption. In the rest of the euro area, the effects are similar but weaker. 

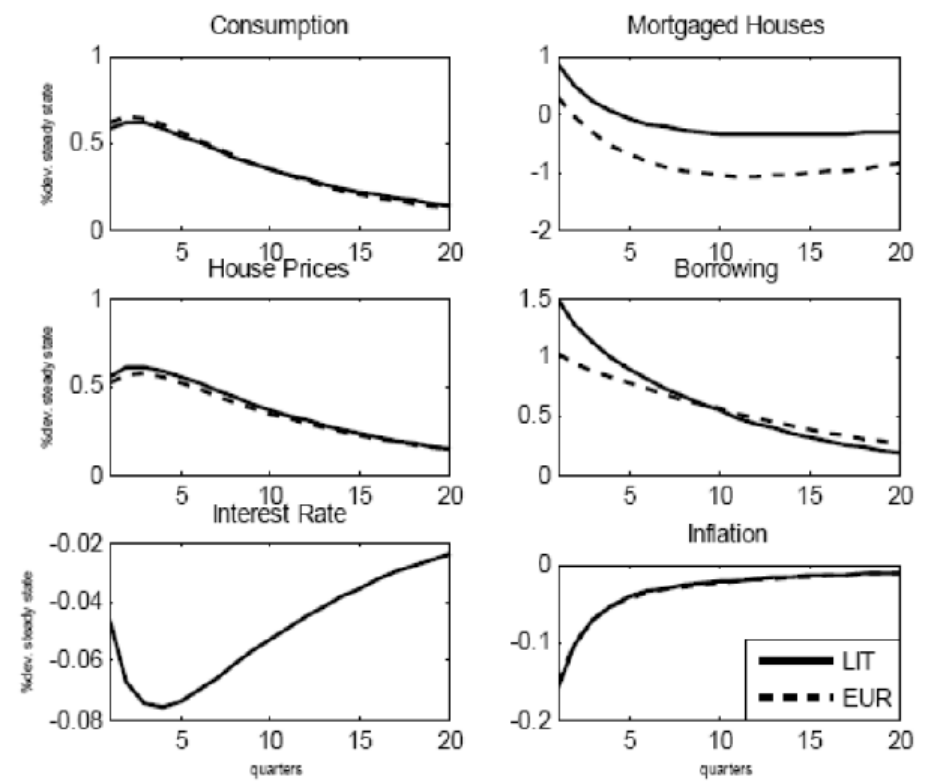

Figure 2: Impulse Responses to a Technology shock

\section{Optimal Macroprudential Policy}

In this section, we search for the optimal macroprudential policy, in the sense that it maximizes country's welfare. We assume that macroprudential policy is taken at a national level and that both countries take the ECB policy as given when deciding on their macroprudential policies.

\subsection{Optimal Parameters}

Table 3 presents the optimized parameters for the macroprudential rules, in particular the ones described in equations (26) and (27). We take monetary policy as given and search over the parameters that maximize welfare in each country simultaneously. ${ }^{32}$

Table 3: Optimal Macroprudential Policy

\begin{tabular}{ll}
$\phi_{E U R}^{b *}$ & 1.9 \\
$\phi_{L I T}^{b *}$ & 0.7 \\
\hline \hline
\end{tabular}

The first row of Table 3 corresponds to the optimal macroprudential policy in the rest of the euro area. In the second row, Lithuania optimizes its macroprudential policy to maximize its welfare. ${ }^{33} \mathrm{We}$

\footnotetext{
${ }^{32}$ As in Angelini et al. (2014), given that regulations are not microfounded here, we adopt a positive approach along the paper. Second-order values should not be taken as normative. That is, we take the presence of the macroprudential regulator as given and study the effects of the regulation on the economy.

${ }^{33}$ Here we follow Angelini et al. (2014) in which they assume that the loss function in the economy also contains financial variables, namely borrowing variability, as a proxy for financial stability. Then, there would be a loss function
} 

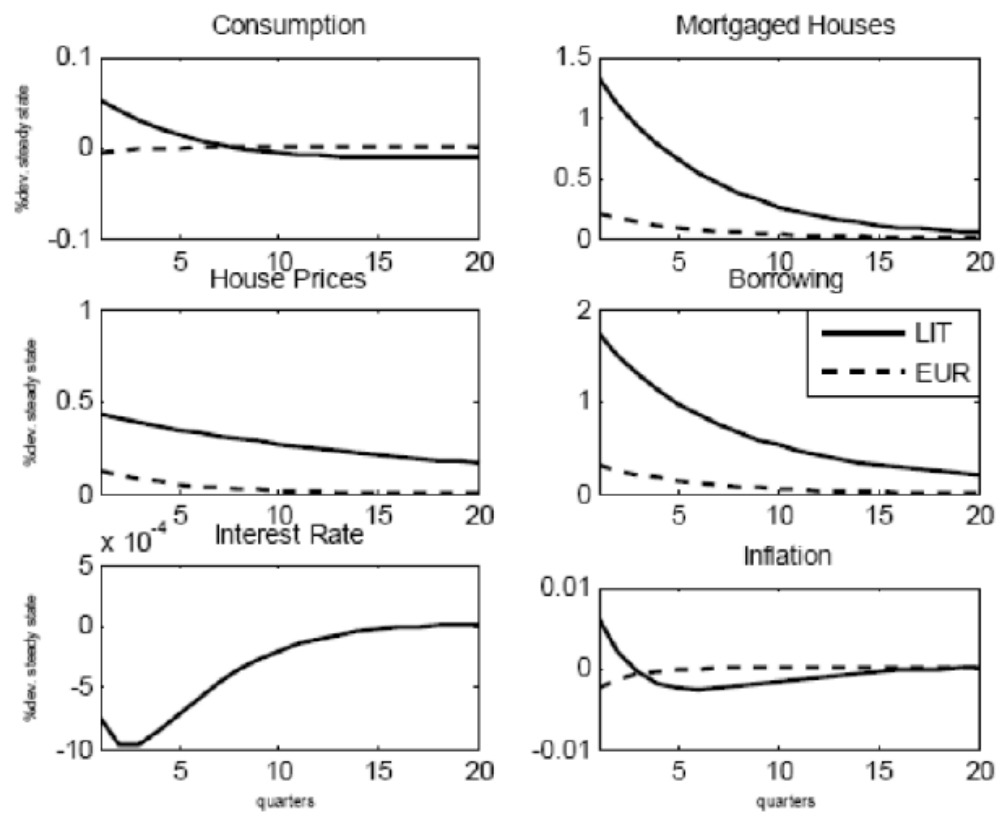

Figure 3: Impulse Responses to a House Price shock

see that the optimal policy in Lithuania may have a different intensity compared to the rest of the euro area. This is maily due to the variable rates that predominate in Lithuania. In the rest of the euro area, with fixed rates, monetary policy is less effective and macroprudential policies can compensate for this fact.

\begin{tabular}{cc}
\hline Table 4: Welfare Gain \\
\hline \hline EUR & 4.40 \\
Borrowers & 10.25 \\
Savers & -0.52 \\
\hline \hline LIT & 0.40 \\
Borrowers & 1.45 \\
Savers & -0.42 \\
\hline \hline Union & 4.37 \\
\hline \hline
\end{tabular}

Then, in Table 4, using the optimal parameters just described above, we present the gains in terms of welfare (in consumption equivalents) that implementing this optimal rule represents. As in Ascari for the economy that would include not only the variability of output and inflation but also the variability of borrowing: $L=\sigma_{\pi}^{2}+\lambda_{y} \sigma_{y}^{2}+\sigma_{b}^{2}$ where $\sigma_{\pi}^{2}, \sigma_{y}^{2}$ and $\sigma_{b}^{2}$ are the variances of inflation, output and borrowing. $\lambda_{y} \geq 0$, represents the relative weight of the central bank to the stabilization of output. 
and Ropele (2009), we find the constant fraction of steady-state consumption that would have to be transferred to the agent if there were a welfare loss under the new parameterization. ${ }^{34}$ Here, a positive value of consumption units represents a welfare increase, that is, how much the agent would pay in units of consumption in order to be better off. A negative value means that welfare was decreasing, that is, by how much an agent should be compensated in units of consumption. We take as a benchmark the case in which there are no macroprudential policies in place.

We can observe from Table 4 that macroprudential policies are welfare enhancing in both regions. In models with collateral constraints, macroprudential policies deliver welfare gains because of the externality coming from the constraint. In this kind of models, the collateral constraint is always binding and, therefore, borrowers are not able to smooth consumption as savers do. Thus, a policy that enhances financial stability brings them a more stable scenario with a more stable consumption path. ${ }^{35}$ However, as usual in this kind of models, there is a trade-off between borrowers and savers. Savers are worse off with macroprudential policy because, in this model, the sticky-price assumption is creating a distortion that affects them. Since they are the owners of the firms, ideally they would like to live in a world in which there is price stability, the goal of monetary policy. If monetary policy loses effectiveness with the presence of macroprudential policies, savers may not like the latter ones ${ }^{36}$. In the aggregate, the economy benefits from macroprudential policies but the gain is coming from the borrower's side.

\footnotetext{
${ }^{34}$ The consumption equivalent measure for the saver, as in Ascari and Ropele $(2009)$ is given by $1-\exp \left[(1-\beta)\left(V_{u, n e w}-\right.\right.$ $\left.V_{u, o l d}\right]$, and analogously for the other agents.

${ }^{35}$ In other words, if the financial system is very unstable and the asset prices (house prices in this framework) are very volatile, borrowers' consumption will be also very volatile since it depends on the value of the collateral.

${ }^{36}$ Allowing for fiscal redistribution would bring a Pareto improvement. However, we do not consider fiscal mechanism in this article. Our aim is here to stress the impact of optimal macroprudential policies for agents and inside the two countries.
} 


\begin{tabular}{|c|c|c|}
\hline & No Macropru & Macropru \\
\hline \multicolumn{3}{|c|}{ EUR } \\
\hline$\sigma_{y}$ & 1.99 & 1.98 \\
\hline$\sigma_{\pi}$ & 0.22 & 0.23 \\
\hline$\sigma_{b}$ & 3.23 & 0.55 \\
\hline \multicolumn{3}{|c|}{ LIT } \\
\hline$\sigma_{y}$ & 1.99 & 1.98 \\
\hline$\sigma_{\pi}$ & 0.22 & 0.23 \\
\hline$\sigma_{b}$ & 2.83 & 1.08 \\
\hline
\end{tabular}

Table 5 displays both macroeconomic and financial volatilities to help us understand where the welfare gains come from. We calculate the standard deviations for output, inflation and borrowing for Lithuania and the rest of the euro area. Our benchmark is the case in which there are no macroprudential policies in place (first column). Then, we see how these volatilities change when we consider the optimized parameters obtained in Table 3 (second column of Table 5). We can observe that, when the macroprudential policy is introduced, the economy benefits from a more stable economy, both in terms of output and borrowing. ${ }^{37}$ This comes at the expense of larger volatility of inflation in our model, because of the differences that may arise between macroprudential and monetary policies, in the context of supply-side shocks. ${ }^{38}$

\section{Concluding Remarks}

In this paper we develop a two-country DSGE model with housing to study the implications of the entrance of Lithuania in the euro area. One of the countries is calibrated to reflect the Lithuanian economy, while the other one represents the rest of the euro area.

First, we study how common shocks transmit in a different way in both regions. In particular, results show that common shocks (monetary policy, technology or house price shocks) are transmitted in a stronger way in Lithuania than in the rest of the euro area, given that the former country has variable-rate mortgages and a higher LTV ratio than its European partners.

\footnotetext{
${ }^{37}$ Notice that this macroprudential policy involves only a short-term output cost, since the policy does not represent a change in the steady state. Welfare benefits are long term.

${ }^{38}$ See Rubio and Carrasco-Gallego (2015) for a detailed explanation of the policy conflicts.
} 
Then, we analyze how macroprudential policies should be conducted in this context. We approximate macroprudential policies as a rule for the (cap) LTV setting that responds to deviations of credit from its steady state. With respect to macroprudential policies, we find that the optimal policy is that Lithuania may have a different intensity in its LTV setting than the rest of the euro area, given that monetary policy is more effective in this country. We also find that the LTV rule is welfare enhancing for the whole monetary union, although there exists a welfare trade-off between borrowers and savers. This is explained because, on the one hand, macroprudential policies bring a more stable financial system but, on the other hand, monetary policy may be less effective and inflation volatility can increase. 


\section{References}

[1] Andrés, J., Arce, O., (2008), "Banking Competition, Housing Prices and Macroeconomic Stability ", Bank of Spain Working Paper, 0830

[2] Andres, J., Arce, O., Thomas, C., (2013), "Banking Competition, Collateral Constraints, and Optimal Monetary Policy ", Journal of Money, Credit and Banking, Supplement to Vol 45, No 2

[3] Angelini, P. Neri, S., Panetta, F., (2012), "Monetary and Macroprudential Policies ", Working Paper Series 1449, European Central Bank.

[4] Ascari, G., Ropele, T., (2009), "Disinflation in a DSGE Perspective: Sacrifice Ratio or Welfare Gain Ratio?", Kiel Institute for the World Economy Working Paper, 1499

[5] Aspachs, O., Rabanal, P., (2010), "The Drivers of Housing Prices in Spain", SERIEs, 1 (1), 101-130

[6] Bank of Lithuania, (2013, 2014, 2015), Financial Stability Review

[7] Benigno, P., Woodford, M., (2012), "Linear-Quadratic Approximation of Optimal Policy Problems", Journal of Economic Theory, Elsevier, vol. 147(1), pages 1-42.

[8] Brzoza-Brzezina, M.\& Kolasa, M. \& Krzysztof, M., 2015. "Macroprudential policy and imbalances in the euro area," Journal of International Money and Finance, Elsevier, vol. 51(C), pages 137-154.

[9] Calza, A., Monacelli, T., Stracca, L., (2009), Housing Finance and Monetary Policy, Working Paper Series 1069, European Central Bank.

[10] Calvo, G., (1983), "Staggered prices in a utility-maximizing framework," Journal of Monetary Economics, 12 (3), 383-398

[11] Domeij, D., Flodén, M., (2006), "The Labor-Supply Elasticity and Borrowing Constraints: Why Estimates are Biased", Review of Economic Dynamics, 9, 242-262

[12] Drehmann, M., Borio, C., Gambacorta, L., Jiménez, G., Trucharte, C., (2010), Countercyclical capital buffers: exploring options, BIS Working Papers, 317 
[13] Ehrmann, M. and Ziegelmeyer, M. (2014), "Household risk management and actual mortgage choice in the euro area", Working Paper Series 1631, European Central Bank.

[14] Errit G. and Uuskula L. (2014), "Euro area monetary policy transmission in Estonia". Baltic Journal of Economics, 14(1-2):55-77

[15] Funke, M., Paetz, M., (2012), "A DSGE-Based Assessment of Nonlinear Loan-to-Value Policies: Evidence from Hong Kong ", BOFIT Discussion Paper No. 11/2012.

[16] Galati, G. and R. Moessner, (2011), "Macroprudential policy - a literature review", BIS Working Papers No 337 .

[17] Gelain, P., Lansing, K., Mendicino, C., (2013), "House Prices, Credit Growth, and Excess Volatility: Implications for Monetary and Macroprudential Policy", International Journal of Central Banking, $9(2)$

[18] Georgiadis, G. (2015), "Examining asymmetries in the transmission of monetary policy in the Euro Area: evidence from a mixed cross-section global VAR model". European Economic Review, $75: 195-215$

[19] Gilchrist, S., Hairault, J., Kempf, H., (2002), "Monetary Policy and the Financial Accelerator in a Monetary Union ", Working Paper Series 1175, European Central Bank.

[20] Gruss, B., Sgherri, S., (2009), "The Volatility Costs of Procyclical Lending Standards: An Assessment Using a DSGE Model ", IMF Working Paper, 09/35.

[21] Iacoviello, M., (2005), "House Prices, Borrowing Constraints and Monetary Policy in the Business Cycle", American Economic Review, 95 (3), 739-764

[22] Iacoviello, M., (2013), "Financial Business Cycles", Mimeo, Federal Reserve Board

[23] Iacoviello, M., Neri, S., (2010), "Housing Market Spillovers: Evidence from an estimated DSGE Model", American Economic Journal: Macroeconomics, American Economic Association, 2 (2), 125-64

[24] Iacoviello, M., Smets, F., (2006), "House Prices and the Transmission Mechanism in the Euro Area: Theory and Evidence from a Monetary Union Model ", mimeo 
[25] IMF, (2008), World Economic Outlook April 2008, International Monetary Fund.

[26] Kannan, P., Rabanal, P., Scott, A., (2012), "Monetary and Macroprudential Policy Rules in a Model with House Price Booms", The B.E. Journal of Macroeconomics, Contributions, 12 (1)

[27] Karmaziene, E., Varanauskiene, J., (2014), "Selection of Short-Term Fixed Interest Rate Mortgages in an Emerging Market: The Case of Lithuania", Bank of Lithuania Working Paper 16/2014

[28] Kydland, F., Prescott, E., (1982). "Time to Build and Aggregate Fluctuations", Econometrica 50, (6), 1345-1370

[29] Lambertini, L., Mendicino, C., Punzi, M., (2013), "Leaning against boom-bust cycles in credit and housing prices", Journal of Economic Dynamics and Control, 37 (8)

[30] Maclennan, D., Muellbauer, J., Stephens, M., (1998), "Asymmetries in Housing and Financial Market Institutions and EMU", Oxford Review of Economic Policy, 4 (3)

[31] Matkėnaitè, S., Ramanauskas, T. and Reichenbachas, T. (2016), "Paskolos ir užstato vertės santykio ribojimo Lietuvoje ekonominiai aspektai ", Teminiu Straipsniu Serija, 2016 n.9 (in Lithuanian), Bank of Lithuania.

[32] McCallum, B., (2001), "Should Monetary Policy Respond Strongly To Output Gaps?," American Economic Review, 91(2), 258-262

[33] Mendicino, C., Pescatori, A., (2007), Credit Frictions, Housing Prices and Optimal Monetary Policy Rules, mimeo

[34] Monacelli, T., (2006), "Optimal Monetary Policy with Collateralized Household Debt and Borrowing Constraint," in conference proceedings "Monetary Policy and Asset Prices" edited by J. Campbell.

[35] Monacelli, T., (2009), "New Keynesian Models, Durable Goods, and Collateral Constraints," Journal of Monetary Economics 56, 242-254

[36] Quint, D., Rabanal, P., (2011), "Monetary and Macroprudential Policy in an Estimated DSGE Model of the Euro Area", Paper presented at the 12th Jacques Polak Annual Research Conference

[37] Rubio, M., (2011), "Fixed- and Variable-Rate Mortgages, Business Cycles, and Monetary Policy," Journal of Money, Credit and Banking, 43 (4), 657-688 
[38] Rubio, M., (2014), "Housing Market Heterogeneity in a Monetary Union," Journal of International Money and Finance, 40

[39] Rubio, M., Carrasco-Gallego, J.A., (2013), "Macroprudential Measures, Housing Markets, and Monetary Policy," Moneda y Credito, 235

[40] Rubio, M., Carrasco-Gallego, J.A., (2014), "Macroprudential and Monetary Policies: Implications for Financial Stability and Welfare", Journal of Banking and Finance, 49, 326-336.

[41] Schmitt-Grohe, S., Uribe, M., (2004), "Solving Dynamic General Equilibrium Models Using a Second-Order Approximation to the Policy Function," Journal of Economic Dynamics and Control, $28,755-775$

[42] Stakenas J. and Stasiukynaitė R. (2016), "Monetary policy transmission: the case of Lithuania", Working Paper Series No. 24/2016, Bank of Lithuania.

[43] Task Force of the Monetary Policy Committee of the European System of Central Banks, (2009), "Housing Finance in the Euro Area", ECB Occasional Paper Series, 101 